\title{
Эколого-биологические особенности Gentiana cruciata L. (Gentianaceae) на юге Томской области
}

\section{Ecological and biological features of Gentiana cruciata L. (Gentianaceae) in the south of the Tomsk region}

\author{
Катаева Т. Н., Прокопьев А. С. \\ Kataeva T. N., Prokopyev A. S. \\ Национальный исследовательский Томский государственный университет, Сибирский ботанический сад, г. Томск, Россия. \\ E-mail: gentianka@mail.ru
}

National Research Tomsk State University, Siberian Botanical Garden, Tomsk, Russia

\begin{abstract}
Peферат. Приводятся результаты изучения распространения, фитоценотической приуроченности, возрастной структуры ценопопуляции и репродуктивных особенностей Gentiana cruciata L. на юге Томской области. Вид отмечен в составе разнотравно-злакового лугового сообества, где выступает содоминантом. Ценопопуляция характеризуется левосторонним типом онтогенетического спектра, является нормальной неполночленной, зреющей. Самоподдержание осуществляется семенным путем.
\end{abstract}

Ключевые слова. Возрастная структура ценопопуляции, семенная продуктивность, Томская область, фитоценотическая приуроченность, Gentiana cruciata.

Summary. The results of studying the distribution, phytocenotic confinement, age structure of coenopopulation and reproductive peculiarities of Gentiana cruciata L. in the south of the Tomsk region are presented. The species is noted in the composition of the forb-grass meadow community, where it acts as a codominant. Cenopopulation is characterized by a left-side type of ontogenetic spectrum, is normal, incomplete, maturing. Self-maintenance is carried out by seed.

Key words. Gentiana cruciata, phytocoenotic confinement, ontogenetic structure, seed productivity, Tomsk Region.

Виды семейства Gentianaceae (горечавковые) имеют большое практическое значение в жизни человека. Они представляют значительный интерес как ценные лекарственные растения, многие из них отличаются высокими декоративными качествами, а также являются редкими и охраняемыми видами (Катаева, Прокопьев, 2017). Решение вопросов практического использования и охраны ценных объектов природной флоры неотъемлемо связано с изучением биологических особенностей вида, прежде всего в природных условиях. Зная биологию вида в конкретных местообитаниях, можно прогнозировать устойчивость его ценопопуляций и ход ответных реакций на неблагоприятные факторы окружающей среды.

Объектом нашего исследования послужил достаточно редко встречающийся в Западной Сибири вид - Gentiana cruciata L. (горечавка крестовидная). В составе флоры Томской области г. крестовидная впервые была отмечена в 2013 г. (Прокопьев и др., 2015). В Западной Сибири охраняется только на территории Омской области (Красная..., 2015). В тоже время во многих регионах Европейской части России занесена в список охраняемых растений. Считаем, что данный вид также стоит рекомендовать для внесения в Красную книгу Томской области.

Полевые работы проводились на территории Томь-Яйского междуречья, близ окр. с. Батурино, на территории ООПТ Государственный ландшафтный заказник областного значения «Ларинский» (Томский р-он). Изначально было обнаружено несколько цветущих и вегетирующих особей G. cruciata (Прокопьев и др., 2015). В ходе последующих маршрутных обследований растительности долины p. Тугояковки была отмечена наиболее многочисленная ценопопуляция исследуемого вида (N 56¹4'16.2", Е 8457'49.2") (рис.). 
G. cruciata - лесостепной вид с севро-западноазиатским типом ареала. Область распространения охватывает Европу, Средиземноморье, Малую и Среднюю Азию, Крым, Кавказ, Западную Сибирь (Цвелев, 1978). В Средней России встречается во всех областях. Растет на суходольных и остепненных лугах, в разреженных лесах. Предпочитает участки с неглубоким залеганием карбонатных пород (Губанов и др., 2004). В Западной Сибири встречается по югу, преимущественно в пределах лесостепной зоны (Шауло, 2000; Лащинский, Лащинская, 2007; Эбель, 2012). Местонахождения вида известны в

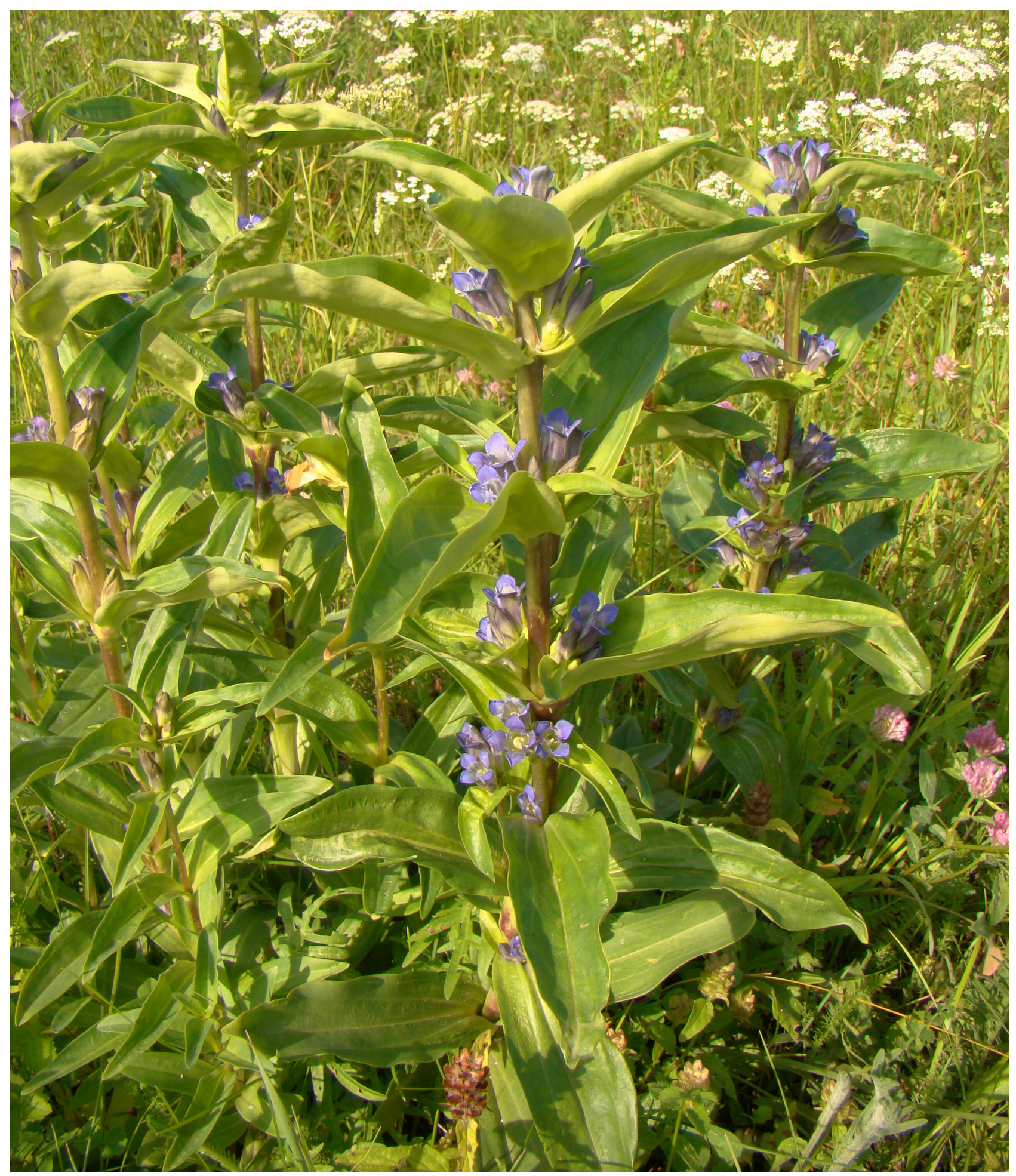

Рис. Gentiana cruciata в окр. с. Батурино (Томский р-н). 
Тюменской, Курганской, Омской и Новосибирской областях (Зуев, 1997). В современных обобщающих сводках и работах, выполненных по флоре Томской области, г. крестовидная не указывается (Вылцан, 1969, 1994; Зуев, 1997; Пяк, 1992, 2014). Таким образом, находка G. cruciata на юге Томской области является самым северо-восточным местонахождением этого вида в Западной Сибири (Прокопьев и др., 2015).

В долине р. Тугояковки G. cruciata встречается в составе разнотравно-злакового лугового сообщества, относящегося к классу формаций настоящих суходольных лугов. На территории Томь-Яйского междуречья эти луга развиваются на хорошо дренируемых местообитаниях и характеризуются высоким фитоценотическим разнообразием, обусловленным положением данной территории в краевой части Западно-Сибирской равнины на стыке ее с отрогами Кузнецкого Алатау (Тищенко, 2017).

Травостой густой, равномерно сомкнутый, подразделяется на несколько подъярусов. Общее проективное покрытие достигает $95 \%$. Основу сообщества формируют типично луговые злаки и разнотравье. Верхний подъярус высотой до 120 см образован генеративными побегами Bromopsis inermis, Centaurea scabiosa, Dactylis glomerata и Picris hieracioides. В среднем, наиболее сомкнутом, подъярусе высотой до 70 см доминируют луговые злаки (Festuca pratensis, Phleum pratense, Poa pratensis) и разнотравье из Achillea asiatica, Gentiana cruciata, Leucanthemum vulgare, Pimpinella saxifraga, Ranunculus polyanthemos, Trifolium pratense. Нижний подъярус высотой до 20 см сложен Plantago major, P. urvillei, Prunella vulgaris, Trifolium repens, Veronica chamaedrys. Видовое богатство исследуемого участка луга насчитывает 45 видов. Регулярное использование его в качестве выпаса приводит к частичному выбиванию травостоя копытами животных, в результате чего на отдельных участках получают возможность расселяться типичные виды нарушенных сообществ - Carduus crispus, Galeopsis bifida, Taraxacum officinale и др.

Площадь, занимаемая ценопопуляцией G. cruciata, составляет 1,4 га. В границах фитоценоза вид выступает содоминантом, распределен равномерно или образует небольшие группы, состоящие из разновозрастных особей. Его экологическая и эффективная плотности составляют 3,7 и 2,6 ос./ м $^{2}$ соответственно (табл.). Взрослые растения средневозрастного состояния могут образовывать от 3 до 8 генеративных побегов на особь.

Таблица

Демографические характеристики Gentiana cruciata в окр. с. Батурино

\begin{tabular}{|c|c|c|c|c|c|c|c|c|c|c|c|c|}
\hline \multicolumn{7}{|c|}{ Онтогенетическое состояние, \% } & \multicolumn{5}{|c|}{ Демографические показатели } \\
\hline $\mathrm{j}$ & $\mathrm{im}$ & $\mathrm{v}$ & $\mathrm{g}_{1}$ & $\mathrm{~g}_{2}$ & $\mathrm{~g}_{3}$ & $\mathrm{ss}$ & $\mathrm{s}$ & $\begin{array}{c}\mathrm{M}, \mathrm{oc} / \\
\mathrm{M}^{2}\end{array}$ & $\begin{array}{c}\mathrm{Me}, \mathrm{oc} / \\
\mathrm{M}^{2}\end{array}$ & $\Delta$ & $\omega$ & Тип ЦП \\
\hline 3,0 & 1,5 & 28,8 & 37,9 & 22,7 & 4,6 & 1,5 & 0 & 3,7 & 2,6 & 0,30 & 0,69 & зреющая \\
\hline
\end{tabular}

Примечание: Онтогенетические состояния особей: $\mathrm{j}$ - ювенильная, im - имматурная, v - виргинильная, $\mathrm{g}_{1}-$ молодая генеративная, $\mathrm{g}_{2}$ - средневозрастная генеративная, $\mathrm{g}_{3}$ - старая генеративная, ss - субсенильная, s - сенильная; М - экологическая плотность, Ме - эффективная плотность, $\Delta$ - индекс возрастности (по А. А. Уранову, 1975), $\omega-$ индекс эффективности (по Л. А. Животовскому, 2001).

Изучение основных репродуктивных характеристик G. cruciata выявило для этого вида по многим показателям высокие значения. Пыльца отличается высокой фертильностью $(95,8$ \%) и способностью к прорастанию $(88,0$ \%). Количество образующихся на побег цветков и плодов хотя и невелико в среднем до 30 , но их равное количество определяет максимально возможный для растений процент плодоцветения - $100 \%$. Особи в среднем на побег формируют 7230 семяпочек и 5358 семян. Несмотря на выраженную разницу между потенциальной и реальной семенной продуктивностью, коэффициент семенификации сохраняет значения выше среднего и составляет 74,1 \%. В целом репродуктивный потенциал исследуемого вида в природных условиях юга Томской области реализуется на достаточно высоком уровне.

Возрастная структура ценопопуляции $G$. cruciata характеризуется левосторонним типом онтогенетического спектра с максимумом на особях молодого генеративного состояния (37,9 \%). Значитель- 
ную долю в ценопопуляции составляют особи виргинильного $(28,8$ \%) и средневозрастного генеративного $(22,7 \%)$ состояний. Доля ювенильных и имматурных растений не превышает 5 \%. Низкие показатели участия особей ранних стадий развития обусловлены значительной степенью задернованности почвы, заметно снижающей выживаемость проростков. Накопление особей генеративной фракции $(65,2 \%)$ связано с продолжительным периодом развития данной онтогенетической группы. Постгенеративная фракция выражена слабо и представлена только особями субсенильного состояния, составляющими в ценопопуляции всего 1,5 \% (табл.). Анализ распределения по онтогенетическим группам в целом выявил количественное преобладание молодой фракции растений $\left(\mathrm{j}-\mathrm{g}_{1}\right)-71,2 \%$, свидетельствующей о значительной устойчивости ценопопуляции.

Самоподдержание ценопопуляции G. cruciata осуществляется исключительно семенным путем, что обеспечивается высокими показателями семенной продуктивности и значительным участием особей генеративной фракции. Исследованная ценопопуляция является нормальной, неполночленной (отсутствуют особи сенильного состояния), по классификации «дельта-омега» относится к зреющей $(\Delta=0,30, \omega=0,69)$.

\section{ЛИТЕРАТУРА}

Вылцан Н. Ф. Луга Томской области: автореф. дис. ... канд. биол. наук. - Томск, 1969. - 21 с.

Вылцан Н. Ф. Определитель растений Томской области. - Томск: Изд-во Том. ун-та, 1994. - 301 с.

Губанов И. А., Киселева К. В., Новиков В. С., Тихомиров В. Н. Иллюстрированный определитель растений Средней России. - М.: Тов. науч. изд. КМК, Институт технологических исследований, 2004. - Т. 3. - 520 с.

Животовский Л. А. Онтогенетические состояния, эффективная плотность и классификация популяций растений // Экология, 2001. - № 1. - С. 3-7.

Зуев В. В. Семейство Gentianaceae - Горечавковые // Флора Сибири. - Новосибирск: Наука, 1997. - Т. 11. - С. $56-85$.

Катаева T. Н., Прокопьев А. С. Биологические особенности представителей рода Gentiana (Gentianaceae) в условиях интродукции на юге Томской области // Вестник Томского государственного университета. Биология, 2017. - № 38. - С. 45-67.

Красная книга Омской области / Отв. ред.: Г. Н. Сидоров, Н. В. Пликина. - Омск: Изд-во ОмГПУ, 2015. $636 \mathrm{c}$.

Лащинский Н. Н., Лащинская Н. В. Высшие сосудистые растения // Флора Салаирского кряжа. - Новосибирск: Академическое издание "Гео", 2007. - С. 155-251.

Прокопьев А. С., Катаева Т. Н., Ямбуров М. С. О находке Gentiana cruciata (Gentianaceae) в Томской области // Систематические заметки по материалам Гербария им. П.Н. Крылова Томского государственного университета, 2015. - № 111. - С. 62-64.

Пяк А. И. Флора Юго-Востока Томской области: автореф. дис. ... канд. биол. наук. - Томск, 1992. - 16 с.

Плк А. И. Сем. Горечавковые - Gentianaceae Juss. // Определитель растений Томской области. - Томск: Из-во Том. ун-та, 2014. - С. 238-241.

Тищенко М. П. Суходольные луга юго-восточной части Томь-Яйского междуречья (Томская область) // Растительный мир Азиатской России, 2017. - № 1 (25). - С. 34-55.

Уранов $\boldsymbol{A}$. $\boldsymbol{A}$. Возрастной спектр фитоценопопуляций как функция времени и энергетических волновых процессов // Биол. науки, 1975. - № 2. - С. 7-34.

Цвелев Н. Н. Род Горечавка - Gentiana L. // Флора Европейской части CCCР. - Л.: Наука, 1978. - Т. 3. - С. 57 74.

Шауло Д. Н. Род Горечавка - Gentiana L. // Определитель растений Новосибирской области. - Новосибирск: Наука, 2000. - С. 265-267.

Эбель А. Л. Конспект флоры северо-западной части Алтае-Саянской провинции. - Кемерово: КРЕОО “Ирбис", 2012. -568 с. 